\title{
Global trends in nanomedicine research on triple negative breast cancer: a bibliometric analysis
}

This article was published in the following Dove Press journal:

International Journal of Nanomedicine

\author{
Ramon Handerson Gomes \\ Teles' \\ Herick Fernando Moralles ${ }^{2}$ \\ Márcia Regina Cominetti ${ }^{\mid}$ \\ 'Department of Gerontology, \\ ${ }^{2}$ Department of Production \\ Engineering, Federal University \\ of São Carlos, São Carlos, SP, Brazil
}

Correspondence: Márcia Regina

Cominetti

Department of Gerontology, Federal University of São Carlos, Rod. Washington Luis, Km 235,

São Carlos, SP, Brazil

Email mcominetti@ufscar.br

\begin{abstract}
Nanotechnology has emerged as a promising tool in the clinic to combat several difficult-to-manage diseases, such as cancer, which is the second leading cause of death worldwide. Chemotherapeutic drugs present several limitations such as undesired side effects, low specificity, resistance, and high relapse rates. Triple negative breast cancer (TNBC) is caused by cells that lack specific receptors in their membrane, such as estrogen $(\mathrm{ER}+)$ and progesterone $(\mathrm{PR}+)$ receptors, or by cells that do not express the amplification of human epidermal growth factor receptor-2 (HER-2+). This cancer type has poor prognosis, high relapse rates, and no targeted therapies. Thus, this study aimed to investigate the trends of nanotechnology research in TNBC and compare the contribution of research from different regions, institutions, and authors. A search of the studies published between 2012 and 2017, related to nanotechnology and TNBC, with different keyword combinations, was performed in the Scopus database. The keywords found in this search were grouped into four clusters, in which "breast cancer" was the most mentioned (1,133 times) and the word "MCF-7 cell line" is one of the latest hotspots that appeared in the year 2016. A total of 1,932 articles, which were cited 26,450 times, were identified. The USA accounted for $28.36 \%$ of the articles and $27.61 \%$ of the citations; however, none of its centers appeared in the list of 10 most productive ones in terms of publications. The journals Biomaterials and International Journal of Nanomedicine had the highest number of publications. The USA and China had the highest number of articles produced and cited; however, the highest average citation per article was from Singapore. The studies focused on the research of antineoplastic agents in animal models and cell culture, and these were the most used topics in research with nanotechnology and TNBC.
\end{abstract}

Keywords: oncology, breast cancer, nanotechnology, nanomedicine, bibliometric

\section{Introduction}

Cancer is a term that refers to the rapid growth and division of abnormal cells in a part of the body. ${ }^{1}$ These cells promote alterations in primary tissue and have the ability to invade different parts of the body and spread to other organs ${ }^{2}$ originating metastasis, which constitutes a challenge in cancer treatment. ${ }^{3}$ There are $>100$ types of cancers, and different risk factors contribute to the development of cancers in different sites. ${ }^{4}$ Cancer is the second cause of death and its main risk factor is aging. This fact is alarming, since a double of the population older than 65 years is expected to be affected in the next 20 years, increasing from 616 million to 1,157 billion worldwide. ${ }^{5}$

The most incident type of cancer is the non-melanoma skin for both sexes, followed by prostate cancer in men and breast cancer in women, which affects women the most worldwide. ${ }^{1}$ Breast tumors are categorized into three main classes: those in which cells have estrogen receptor $(\mathrm{ER}+)$ or progesterone receptor $(\mathrm{PR}+)$, those in which cells have human epidermal growth factor receptor-2 (HER-2+) with or without 
$\mathrm{ER}+$, and the triple negative breast cancer (TNBC) defined by the absence of these receptors. ${ }^{6,7}$

TNBC affects $9 \%-16 \%$ of the population worldwide, has a poor prognosis related to cure and survival, has high relapse rates, and has no targeted therapies. ${ }^{8}$ Basically, breast cancer treatment constitutes surgery, chemotherapy, and radiotherapy. ${ }^{9}$ There is an urgent need for chemotherapeutics that act selectively to inhibit neoplastic cell growth, leaving the non-tumor cells intact. ${ }^{10}$ However, the majority of the drugs used in chemotherapy are mutagenic and cause damage to DNA from the tumor and non-tumor cells, leading to the death of rapidly dividing cells, which is associated with the collateral effects observed in patients. ${ }^{11}$

Aiming to improve the efficacy to decrease toxicity and increase the bioavailability of chemotherapy medication, nanotechnology has emerged as an important option. ${ }^{12,13}$ Nanoparticles accumulate preferentially in the tumors due to the presence of well defined characteristics in tumors mass, such as the defective vasculature and poor lymphatic drainage, resulting in an increase in permeation and retention effect. ${ }^{14,15}$ For antitumor treatment, nanoparticles may serve as carriers of compounds with higher selectivity for primary tumor and metastases, reducing the drug resistance and side effects. ${ }^{16}$ In TNBC, gold nanoparticles conjugated with folic acid have shown significantly higher cell entry rates in both in vitro and in vivo models, indicating that folate receptors can be used as targeted therapies for TNBC. ${ }^{17}$ This pattern was also observed with fructose-coated nanoparticles showing high selectivity (100fold) for breast cancer cells compared to normal cells. ${ }^{18-20}$

This review aims to provide an update of the scientific production related to nanoparticles for breast cancer treatment, mainly for the triple negative subtype, during the period between 2012 and 2017.

\section{Materials and methods}

Literature search was performed in August 2017 in Scopus database, using the keywords (nanotechnology OR nanomedicine OR nanoparticle OR drug carrier) AND (triple negative breast cancer OR TNBC OR breast cancer), and was confined to articles published in journals related to Biotechnology, Pharmacology, Toxicology and Pharmaceutics, and Medicine areas, published in the period ranging from 2012 to 2017, and written in English language.

The results regarding authors who are publishing in the field were analyzed through tools in Scopus database. Impact factor (IF) of the journals was analyzed using InCites Journal Citation Reports from Thomson Reuters. VOSviewer version 1.6.0 software (Leiden University, Leiden, the Netherlands) was used to analyze the relationship between the most cited references and the most productive authors to generate the map and clusters visualization. STATA software and Microsoft Excel 2013 were used to calculate the cumulative volume and to predict paper trends using polynomial multiple regression models. GraphPad Prism 5 and RSudio 1.1.383 were used to create graphics.

\section{Results \\ General information}

The initial number of identified studies using the keyword combination was 4,676. After exclusions, the final number was 1,932 , as demonstrated in the flow chart depicted in Figure 1.

In the period ranging from 2012 to 2017, 1,932 papers were published by 7,666 authors on the theme in 425 journals using 14,614 keywords (Table 1). There was a growth in the annual number of papers, from 200 in 2012 to 1,757 in 2016, with a projection of 2,256 for 2017 and 2,798 for 2018. In this period, the increase in the number of publications can be represented by the polynomial regression model: $y=21.93$ $\mathrm{x}^{2}-87,939.19 \mathrm{x}+88,163,841.66$, with $\mathrm{y}$ being the year and $\mathrm{x}$ being the cumulative volume of papers (Figure 2).

For the prediction model, functional specification, linear, logarithmic, polynomial, and exponential equations were tested. Hence, the choice of a second-order polynomial model for Figures 2 and $3 \mathrm{~A}$ and $\mathrm{B}$ was based on the maximization of the $R^{2}$ goodness-of-fit coefficient of the available historical data, from 2012 to 2017, which served as the basis for choosing the model with the highest $R^{2}$.

\section{Countries}

The most productive country in terms of publication, using the keywords already mentioned, was the USA with 548 papers, representing $28.36 \%$ of total publications (Figure 3A). After this, China and India occupied second and third positions, respectively, with 494 (25.56\%; Figure 3B) and 257 (13.30\%) papers (Figure $3 \mathrm{C}$ ). The choice of the functional specification for Figure $3 \mathrm{~A}$ followed the same $R^{2}$ maximization logic; consequently, for the USA, the best specification was linear. This displays that India, China, and the USA show a growing trend in publications. However, the USA has a steady rate, while India and China are growing at increasing rates; thus, the expectation is that by 2018 , China (which has the steepest growth rate) will exceed the USA in the number of publications. The top 10 countries that published more articles from 2012 to 2017 are shown in Figure 3D. 


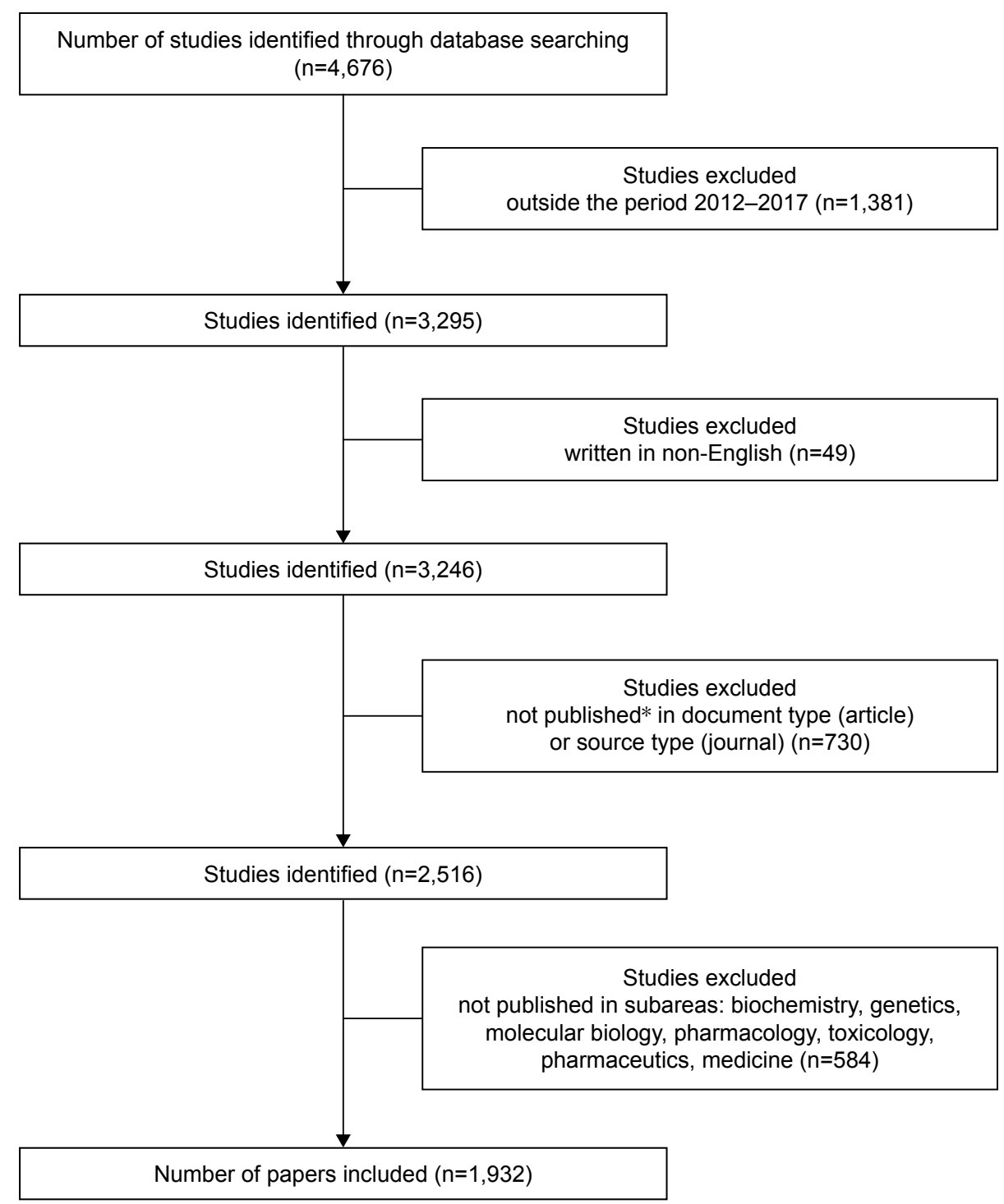

Figure I Flow chart of studies used in the analysis.

Notes: *Document type includes only the articles published in journals. Conference papers, short surveys, editorials, notes, letters, book chapters, and articles in press were excluded. Source type includes only journals. Conference proceedings, book series, and books were excluded from the results.

The papers were cited 26,450 times. The citation frequency was 13.69 times per paper. Singapore was the country that had the highest average of article citations (27 times). The number of citations of all papers from the USA was

Table I General information on articles related to nanotechnology and triple negative breast cancer published in the period from 2012 to 2017

\begin{tabular}{ll}
\hline Articles & 1,932 \\
Articles per author & 0.252 \\
Author per article & 3.97 \\
Coauthor per article & 6.8 \\
Sources (journals) & 425 \\
Keywords & 3,966 \\
Authors & 7,666 \\
\hline
\end{tabular}

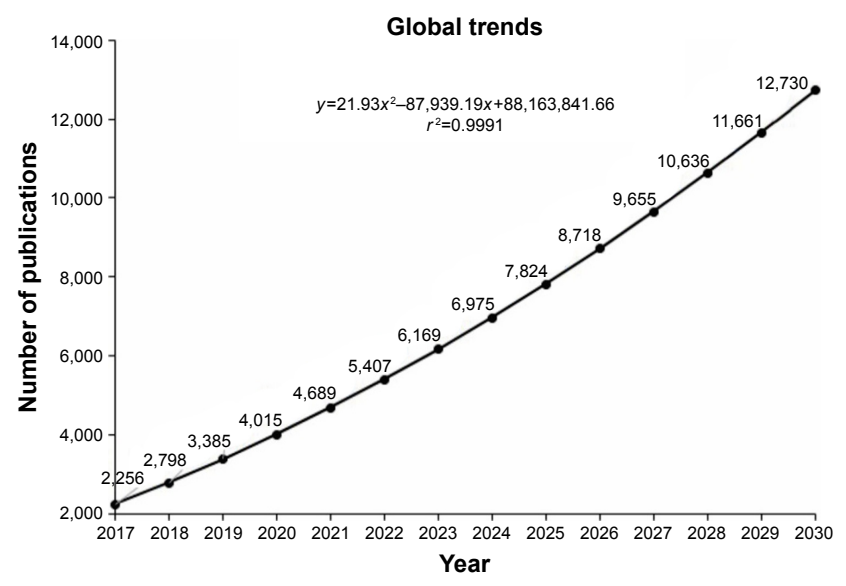

Figure 2 Cumulative volume of articles related to nanotechnology and triple negative breast cancer: global trends for 2030. 

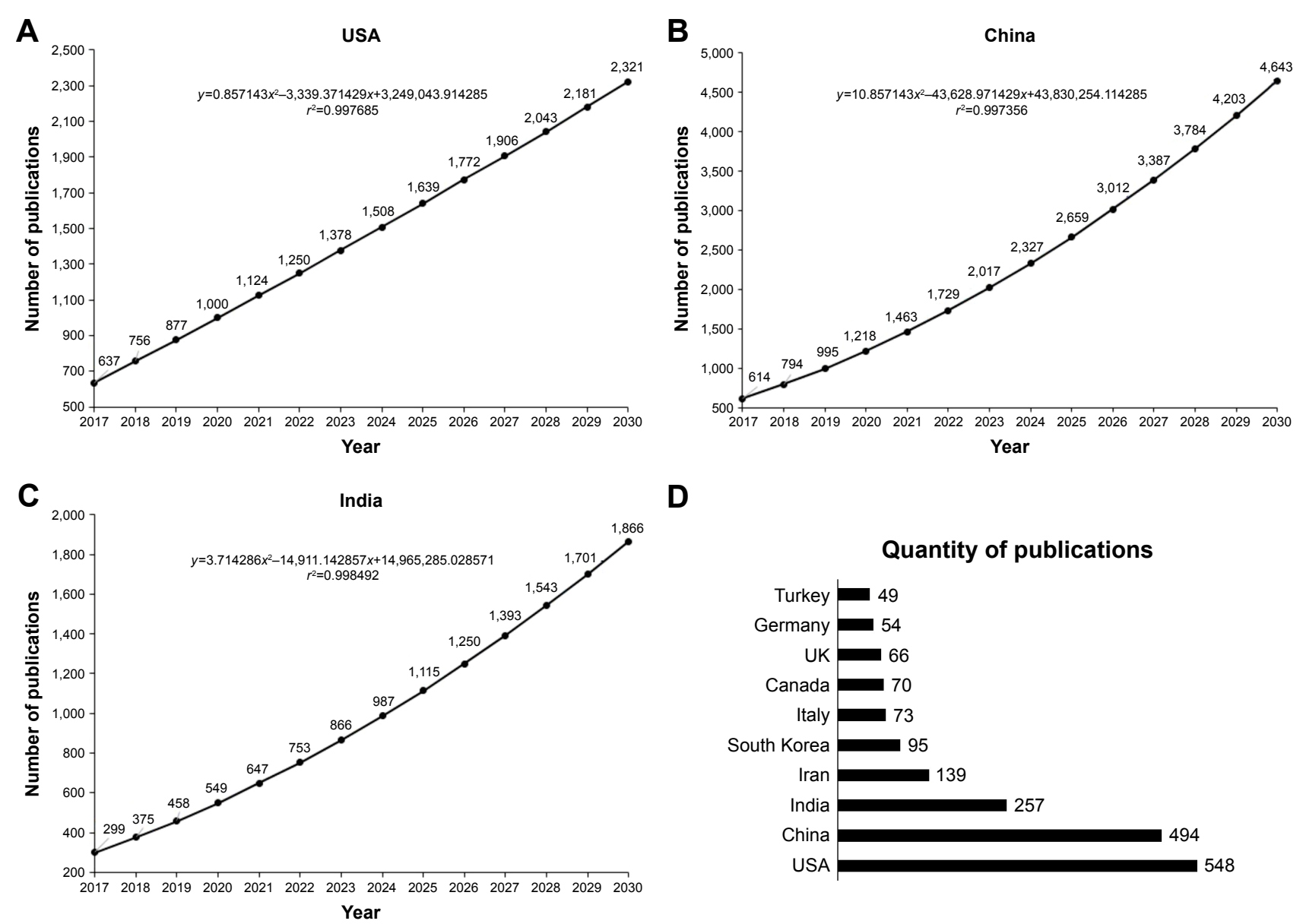

D

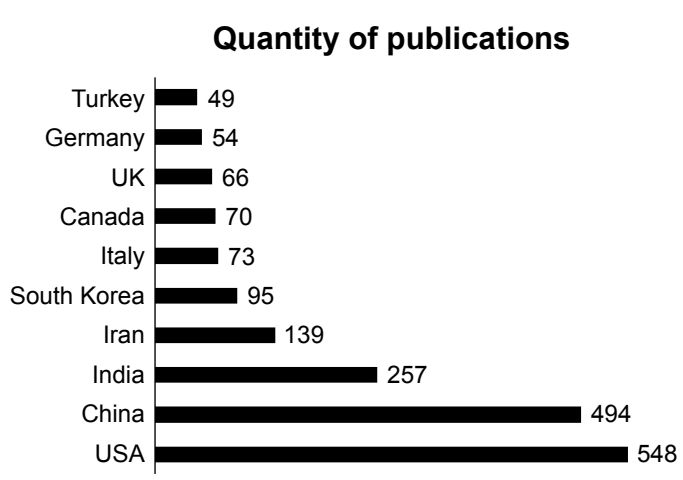

Figure 3 Prediction of the number of publications in the field of nanotechnology and triple negative breast cancer expected until 2030 from (A) India, (B) China, and (C) the USA. (D) Quantity of publications related to nanotechnology and triple negative breast cancer by country during the period $2012-2017$.

7,304 , comprising $27.61 \%$ of the total citations. China was in the second position with 7,126. The top 10 most cited countries are shown in Figure 4.

\section{Institutes}

The institute with the largest number of publications and citations in the area of nanotechnology and TNBC during the period was the Chinese Academy of Sciences, with 99 papers and 1,832 citations, comprising $5.12 \%$ of the total literature, and being the most cited institute. There are five other Chinese institutes in top 10 of the most cited publications and 2 are from Iran (Table 2). The USA was the country that was the most cited; however, the US institutes do not appear among the top 10 that published the most in the field. The M.D. Anderson Cancer Center from the University of Texas with 25 publications and 693 citations

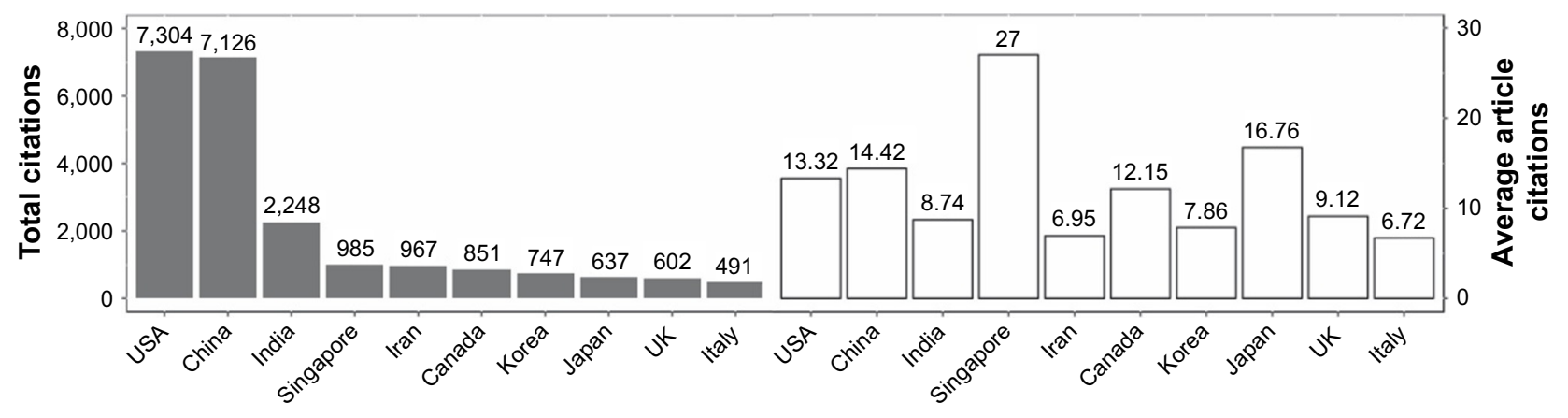

Figure 4 Total and average article citations per country of papers in the area of nanotechnology and triple negative breast cancer during the period $2012-20 I 7$. 
Table 2 Main affiliations of authors publishing in the area of nanotechnology and triple negative breast cancer

\begin{tabular}{lll}
\hline Institute & Documents & Citations \\
\hline Chinese Academy of Sciences & 99 & 1,832 \\
Tehran University of Medical & 56 & 468 \\
Sciences & & \\
Ministry of Education China & 43 & 460 \\
Sichuan University & 38 & 923 \\
Tabriz University of Medical Sciences & 36 & 256 \\
University of Toronto & 32 & 131 \\
Perking University & 29 & 513 \\
National University of Singapore & 28 & 786 \\
Shenyang Pharmaceutical University & 27 & 427 \\
National Center for Nanoscience & 27 & 489 \\
and Technology, Beijing & & \\
\hline
\end{tabular}

and the Harvard Medical School with 18 publications and 616 citations were the American institutes that published the most in the area.

\section{Journals}

The top 10 journals published 625 papers in the area of TNBC and nanotechnology, comprising $32.34 \%$ of the total. Biomaterials (IF 8.402; 2016) had the largest number of publications with 120 papers and was the most cited journal with 4,180 citations, followed by International Journal of Nanomedicine (IF 4.300; 2016) with 113 papers and 1,332 citations and International Journal of Pharmaceutics (IF 3.649; 2016) with 70 documents and 970 citations. The top 10 journals publishing in the area are shown in Table 3.

\section{Authors, patents, and clinical trials}

The top 10 most productive authors had a total of 160 papers, contributing to $8.3 \%$ of all publications in the field. In the period ranging from 2012 to 2017, "Li, Yaping” from Shanghai Institute of Materia Medica (China) produced most papers in the area, with 23 articles. His most cited paper is entitled "Co-delivery of doxorubicin and RNA using $\mathrm{pH}$-sensitive poly ( $\beta$-amino ester) nanoparticles for reversal of multidrug resistance of breast cancer" (2014) with 56 citations. "Atyabi, F" and "Yu, Hainjun" published 18 articles each. Furthermore, during the same period, $>9,000$ patents were filed; thus, the patents filed by the 10 authors who published the most were searched. Of these, four authors filed patents. "Ferrari, Mauro" was the most productive with 10 patents. The top 10 authors in this area are shown in Table 4, and a list of their patents is shown in Table 5 .

We also performed a search on the current scenario of clinical trials in the area of TNBC and nanotechnology using the same combination of keywords described in the section "Materials and methods". The search resulted in 12 studies (Table 6). One study was excluded since it did not involve nanotechnology. Of the remaining 11 studies, 2 have their results reported. Two of them were related to the use of Abraxane ${ }^{\circledR}$ in a combined regimen with carboplatin or carboplatin and bevacizumab. Abraxane is a nanoparticle containing albumin-bound paclitaxel and bevacizumab in an anti-vascular endothelial growth factor antibody.

The results regarding the safety and tolerability for the clinical trial using Abraxane and carboplatin were not presented, according to the report provided, due to insufficient accrual for the study. However, $60 \%$ of patients $(6 / 10)$ presented serious adverse effects, such as anemia, alterations in neutrophil count, gastrointestinal disorders, and allergic reactions, after treatment. All the patients $(10 / 10)$ had other adverse effects such as nausea, edema, and pain. This study was terminated.

The study using Abraxane with carboplatin and bevacizumab involved 41 women with TNBC in stage IV or inoperable stage III. Results of 39 patients were provided. Of them, $18 \%$ had complete response, $69 \%$ had partial

Table 3 Top 10 journals published in the area of nanotechnology and triple negative breast cancer

\begin{tabular}{llll}
\hline Journal & $\begin{array}{l}\text { Impact } \\
\text { factor (2016) }\end{array}$ & Documents & Citations \\
\hline Biomaterials & 8.402 & 120 & 4,018 \\
International Journal of Nanomedicine & 4.300 & 113 & 1,332 \\
International Journal of Pharmaceutics & 3.649 & 70 & 970 \\
Journal of Controlled Release & 7.786 & 61 & 1,198 \\
Colloids and Surfaces B Biointerfaces & 3.887 & 61 & 869 \\
Molecular Pharmaceutics & 4.440 & 60 & 1,201 \\
Nanomedicine Nanotechnology Biology and Medicine & 5.720 & 36 & 550 \\
PLoS One & 2.806 & 36 & 370 \\
Nanomedicine & 4.727 & 34 & 269 \\
Journal of Biomedical Nanotechnology & 4.521 & 34 & 322 \\
\hline
\end{tabular}




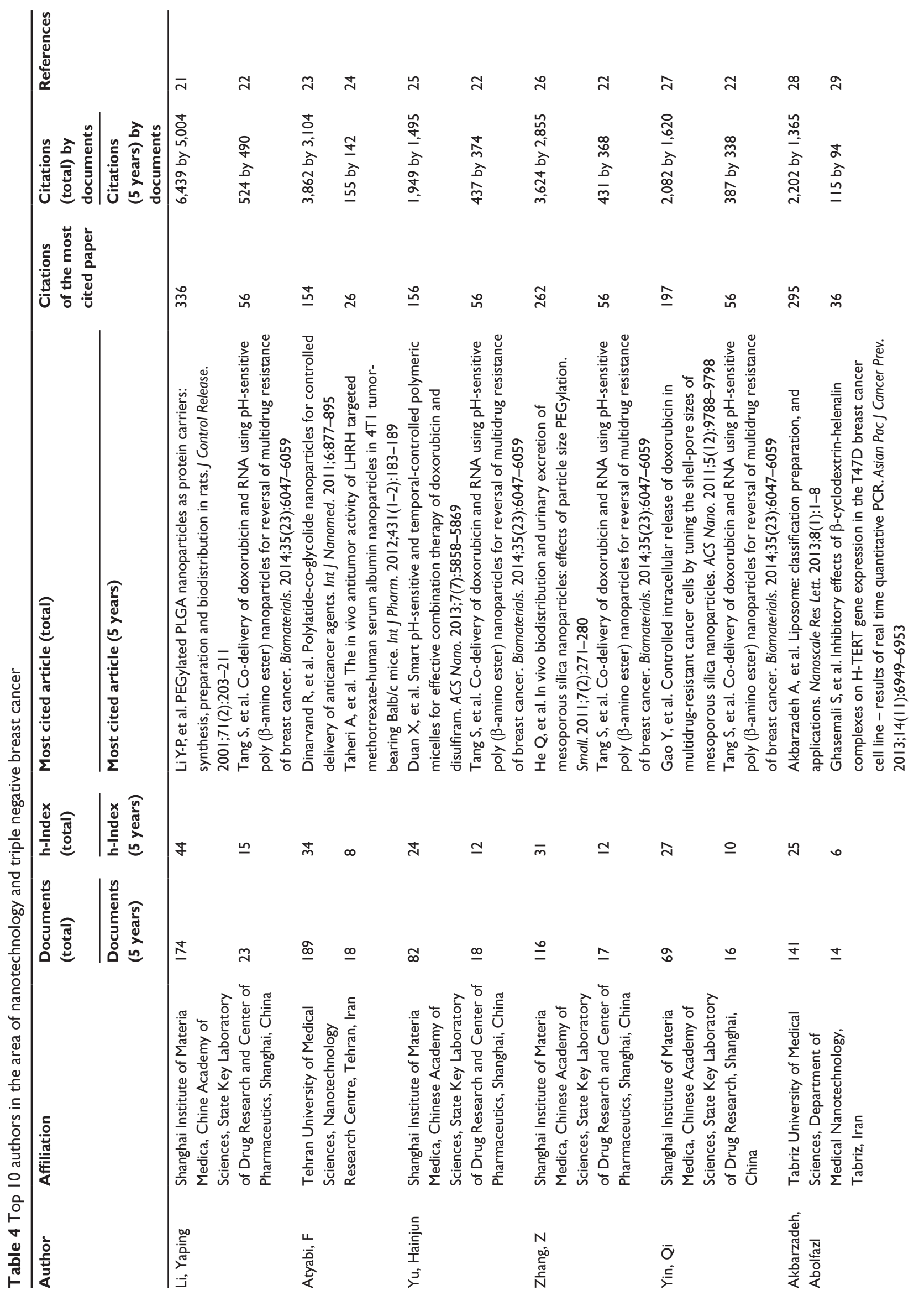




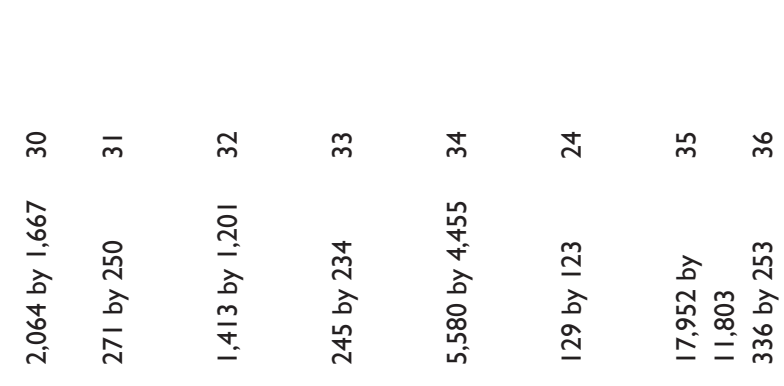

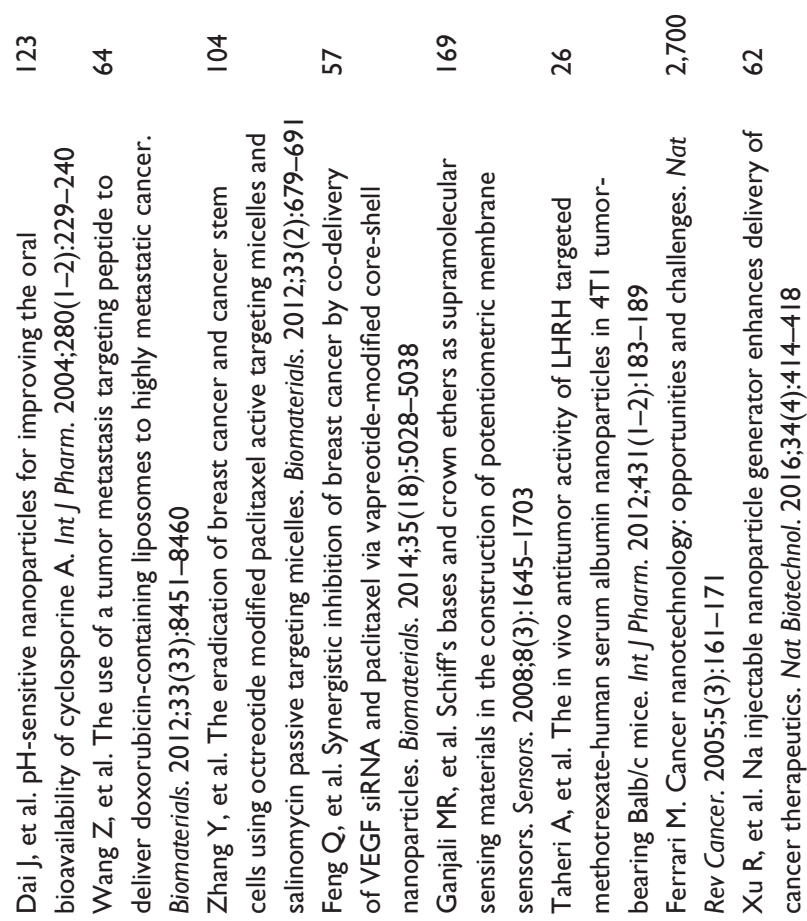

ก $\infty$ ก

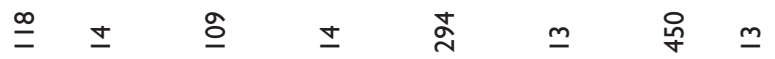

\begin{tabular}{|c|c|c|c|}
\hline 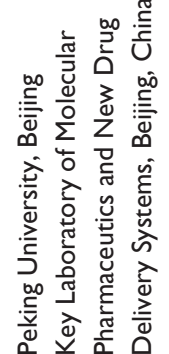 & 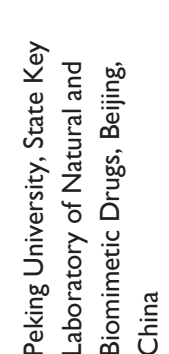 & 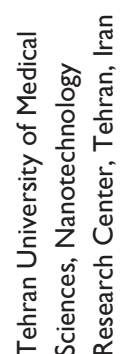 & 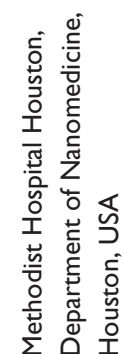 \\
\hline
\end{tabular}

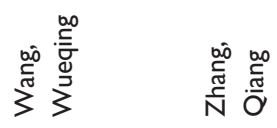

response, $8 \%$ presented stable disease, and only $5 \%$ had progressive disease. The duration of progression-free disease was 15 months; however, $53.66 \%$ and $100 \%$ of the participants had serious adverse effects and other adverse effects, respectively.

Overall, the scenario on TNBC and nanotechnology is not greatly encouraging currently. As in traditional chemotherapy, adverse effects of the regimens seem to be the main cause of concern. Notwithstanding, further research and the introduction of different nanosystems are pivotal for the improvement of therapeutic options for TNBC.

\section{Articles}

The top 10 most cited articles had 2,224 citations, representing $8.4 \%$ of the total citations. The paper entitled "Preclinical development and clinical translation of PSMA-targeted docetaxel nanoparticle with a differentiated pharmacological profile" (2012) published in Science Translational Medicine by HrKach J et al was the most cited, with 445 citations. The top 10 most cited articles are shown in Table 7.

\section{Hotspots}

Keywords of 1,932 articles were analyzed in VOSviewer. Of 14,614 keywords, 145 were used $>85$ times in titles and abstracts of all papers. Keywords were classified into four clusters formed in the software VOSviewer: "Drugs", "Animal Models", "Human cell lines", and "Properties". In the cluster "Drugs", the most used keywords were "breast cancer" (1,133 times), "drug delivery system" (666 times), and "antineoplasic agent" (544 times).

In the cluster "Animal Models", the most used keywords were "unclassified drug" (685 times), "in vitro study" (584 times), and "particle size" (551 times). In the cluster "Human cell lines", the more frequently used keywords were "human" (1,481 times), "humans" (1,340 times), and "chemistry" (855 times). In the cluster "Properties", the most common keywords were "female" (1,023 times), "nonhuman" (802 times), and "animals" (793 times). Keywords and association lines are shown in Figure 5 and listed in Table S1.

Several drugs are used in TNBC treatment, and results of clinical studies demonstrated that TNBC patients have different responses to them. ${ }^{47}$ However, the chemotherapeutic drug widely reported in nanomedicine for the treatment of TNBC was "doxorubicin" (395 times), and the most common carrier nanosystem was "liposome/liposomes" (279 times). Accordingly, during the past few years, various nanomaterials have been developed for the detection and treatment of 
Table 5 Patents filed by the top 10 authors in the area of nanotechnology and triple negative breast cancer

\begin{tabular}{|c|c|c|c|c|c|}
\hline Inventors & Patent name & Applicant & Date of filing & Patent office & $\begin{array}{l}\text { Patent } \\
\text { number }\end{array}$ \\
\hline $\begin{array}{l}\text { Li, Yaping (Pudong Shanghai, CN); } \\
\text { Chen, Lingli (Pudong Shanghai, } \\
\text { CN); Zheng, Zhaolei (Pudong } \\
\text { Shanghai, CN); Zhang, Zhiwen } \\
\text { (Pudong Shanghai, CN); Gu, } \\
\text { Wangwen (Pudong Shanghai, CN) }\end{array}$ & $\begin{array}{l}\text { Irinotecan } \\
\text { hydrochloride } \\
\text { composite } \\
\text { phospholipid } \\
\text { composition, } \\
\text { preparation method } \\
\text { and use thereof }\end{array}$ & $\begin{array}{l}\text { Shanghai Institute } \\
\text { of Materia Medica, } \\
\text { Chinese Academy } \\
\text { Sciences } \\
\text { Shanghai Jingfeng } \\
\text { Pharmaceutical CO., } \\
\text { LTDA }\end{array}$ & March 6, 2015 & $\begin{array}{l}\text { United States } \\
\text { Patent and } \\
\text { Trademark Office } \\
\text { Pre-Granted } \\
\text { Publication United } \\
\text { Kingdom Patent } \\
\text { Application }\end{array}$ & $\begin{array}{l}\text { US20I70087I46 } \\
\text { GB20I600I6625 } \\
20 I 50306\end{array}$ \\
\hline $\begin{array}{l}\text { Gillman, Kevin W (Madison, CT); } \\
\text { Goodrich, Jason (Wallingford, } \\
\text { CT); Boy, Kenneth M } \\
\text { (Durham, CT); Zhang, Yunhui } \\
\text { (Glastonbury, CT); Mapelli, } \\
\text { Claudio (Lawrenceville, NJ); Poss, } \\
\text { Michael A (Lawrenceville, NJ); } \\
\text { Sun, Li-Qiang (Glastonbury, CT); } \\
\text { Zhao, Qian (Wallingford, CT); } \\
\text { Mull, Eric (Guilford, CT); Gillis, } \\
\text { Eric P (Cheshire, CT); Scola, Paul } \\
\text { Michael (Glastonbury, CT) }\end{array}$ & Immunomodulators & $\begin{array}{l}\text { Bristol-Myers Squibb } \\
\text { Company }\end{array}$ & $\begin{array}{l}\text { November II, } \\
2015\end{array}$ & $\begin{array}{l}\text { United States } \\
\text { Patent and } \\
\text { Trademark Office } \\
\text { Pre-Granted } \\
\text { Publication }\end{array}$ & US20160I37696 \\
\hline $\begin{array}{l}\text { Dinarvand, Rassoul (Tehran, IR); } \\
\text { Derakhshan, Mohammad Ali } \\
\text { (Tehran, IR); Rahbarizadeh, } \\
\text { Fatemeh (Tehran, IR); Majidi, } \\
\text { Reza Faridi (Tehran, IR); Borujeni, } \\
\text { Azade Taheri (Tehran, IR); } \\
\text { Rezayat, Seyed Mahdi (Tehran, IR) }\end{array}$ & $\begin{array}{l}\text { Multi-mode } \\
\text { cancer targeted } \\
\text { nanoparticulate } \\
\text { system and } \\
\text { a method of } \\
\text { synthesizing the } \\
\text { same }\end{array}$ & $\begin{array}{l}\text { Dinarvand; Rassoul } \\
\text { Derakhshan; } \\
\text { Mohammad Ali } \\
\text { Rahbarizadeh; } \\
\text { Fatemeh } \\
\text { Majidi; Reza Faridi } \\
\text { Borujeni; Azade } \\
\text { Taheri } \\
\text { Rezayat; Seyed Mahdi }\end{array}$ & $\begin{array}{l}\text { January II, } \\
2012\end{array}$ & $\begin{array}{l}\text { United States } \\
\text { Patent and } \\
\text { Trademark Office } \\
\text { Pre-Granted } \\
\text { Publication }\end{array}$ & US20I30I78603 \\
\hline $\begin{array}{l}\text { Mi, Yu (Houston, TX); Ferrari, } \\
\text { Mauro (Houston, TX) }\end{array}$ & $\begin{array}{l}\text { Micro/nano } \\
\text { composite } \\
\text { drug delivery } \\
\text { formulations and } \\
\text { uses thereof }\end{array}$ & $\begin{array}{l}\text { The Methodist } \\
\text { Hospital (Houston, } \\
\text { TX, USA) }\end{array}$ & $\begin{array}{l}\text { August 25, } \\
2016\end{array}$ & $\begin{array}{l}\text { United States } \\
\text { Patent and } \\
\text { Trademark Office } \\
\text { Pre-Granted } \\
\text { Publication }\end{array}$ & US20I70056327 \\
\hline $\begin{array}{l}\text { Shen, Haifa (Houston, TX); } \\
\text { Ferrari, Mauro (Houston, TX); } \\
\text { Shen, Jian (Houston, TX); Zhang, } \\
\text { Mingzhen (Houston, TX) }\end{array}$ & $\begin{array}{l}\text { Polycation- } \\
\text { functionalized } \\
\text { nanoporous silicon } \\
\text { carrier for systemic } \\
\text { delivery of gene } \\
\text { silencing agents }\end{array}$ & $\begin{array}{l}\text { The Methodist } \\
\text { Hospital (Houston, } \\
\text { TX, USA) }\end{array}$ & $\begin{array}{l}\text { December II, } \\
2015\end{array}$ & $\begin{array}{l}\text { United States } \\
\text { Patent and } \\
\text { Trademark Office } \\
\text { Pre-Granted } \\
\text { Publication }\end{array}$ & US20160369269 \\
\hline $\begin{array}{l}\text { Ferrari, Mauro (Houston, TX); } \\
\text { Tasciotti, Ennio (Houston, TX); } \\
\text { Sakamoto, Jason (Houston, TX) }\end{array}$ & $\begin{array}{l}\text { Multistage delivery } \\
\text { of active agents }\end{array}$ & $\begin{array}{l}\text { Ferrari; Mauro } \\
\text { Tasciotti; Ennio } \\
\text { Sakamoto; Jason }\end{array}$ & May 29,2015 & $\begin{array}{l}\text { United States } \\
\text { Patent and } \\
\text { Trademark Office } \\
\text { Pre-Granted } \\
\text { Publication }\end{array}$ & US20I6005I48I \\
\hline
\end{tabular}

breast cancer. These nanoparticles are made up of a variety of materials including lipids, polymers, silica, protein/peptides, oligonucleotides, and metals such as gold, silver, and iron. ${ }^{48}$ We found in this review that the main materials used in the formulations were "macrogol" (191 times), "macrogol derivate" (177 times), and "polyethylene glycols" (265 times).

VOSviewer applied colors to keywords based on the year that they appeared in the literature. Keywords in red appeared early, followed by yellow and green colors, while keywords in blue appeared later. The average year of cluster appearance was close to each other. The cluster "Drugs" had the more recently used keyword "antineoplasic agent" (544 times cited, year of appearance 2014). The cluster "Animal models" had "Breast cancer cell lines" (231 times cited, 2015), the cluster "Human cell lines" had "MCF-7 cell lines" (165 times cited, 2016), and the cluster "Properties" had "Bagg albino mouse" 
Table 6 Clinical trials in the area of nanotechnology and triple negative breast cancer

\begin{tabular}{|c|c|c|c|c|c|}
\hline Study title & Status & Interventions & First posted & $\begin{array}{l}\text { Sponsors/ } \\
\text { collaborators }\end{array}$ & $\begin{array}{l}\text { Principal } \\
\text { investigators }\end{array}$ \\
\hline $\begin{array}{l}\text { Carboplatin and paclitaxel } \\
\text { albumin-stabilized nanoparticle } \\
\text { formulation before surgery in } \\
\text { treating patients with locally } \\
\text { advanced or inflammatory triple } \\
\text { negative breast cancer }\end{array}$ & Recruiting & $\begin{array}{l}\text { Drug: carboplatin } \\
\text { Drug: paclitaxel albumin- } \\
\text { stabilized nanoparticle } \\
\text { formulation } \\
\text { Other: laboratory } \\
\text { biomarker analysis }\end{array}$ & $\begin{array}{l}\text { February } 3 \\
2012\end{array}$ & $\begin{array}{l}\text { City of Hope } \\
\text { Medical Center } \\
\text { National Cancer } \\
\text { Institute }\end{array}$ & $\begin{array}{l}\text { Yuan Yuan } \\
\text { Stephen C } \\
\text { Koehler }\end{array}$ \\
\hline $\begin{array}{l}\text { A trial of nanoparticle albumin- } \\
\text { bound paclitaxel (nab-paclitaxel, } \\
\text { abraxane }{ }^{\circledR} \text { ) with or without } \\
\text { mifepristone for advanced, } \\
\text { glucocorticoid receptor- } \\
\text { positive, triple negative } \\
\text { breast cancer }\end{array}$ & Recruiting & $\begin{array}{l}\text { Drug: mifepristone } \\
\text { Other: placebo } \\
\text { Drug: nab-paclitaxel }\end{array}$ & June 2, 2016 & $\begin{array}{l}\text { University of } \\
\text { Chicago }\end{array}$ & $\begin{array}{l}\text { Rita Nanda } \\
\text { Gini Fleming }\end{array}$ \\
\hline $\begin{array}{l}\text { Study to evaluate CORTI25I34 } \\
\text { in combination with nab- } \\
\text { paclitaxel in patients with solid } \\
\text { tumors }\end{array}$ & Recruiting & $\begin{array}{l}\text { Drug: CORTI25I34 with } \\
\text { nab-paclitaxel }\end{array}$ & May 5, 2016 & $\begin{array}{l}\text { Corcept } \\
\text { Therapeutics }\end{array}$ & $\begin{array}{l}\text { Thaddeus S } \\
\text { Block }\end{array}$ \\
\hline $\begin{array}{l}\text { Paclitaxel albumin-stabilized } \\
\text { nanoparticle formulation and } \\
\text { bevacizumab followed by } \\
\text { bevacizumab and erlotinib } \\
\text { hydrochloride in treating patients } \\
\text { with metastatic breast cancer }\end{array}$ & $\begin{array}{l}\text { Active, not } \\
\text { recruiting }\end{array}$ & $\begin{array}{l}\text { Drug: paclitaxel albumin- } \\
\text { stabilized nanoparticle } \\
\text { formulation } \\
\text { Biologic: bevacizumab } \\
\text { Drug: erlotinib } \\
\text { hydrochloride } \\
\text { Other: laboratory } \\
\text { biomarker analysis }\end{array}$ & $\begin{array}{l}\text { August 13, } \\
2008\end{array}$ & $\begin{array}{l}\text { National Cancer } \\
\text { Institute } \\
\text { University of } \\
\text { Washington }\end{array}$ & $\begin{array}{l}\text { Jennifer } \\
\text { Specht }\end{array}$ \\
\hline $\begin{array}{l}\text { Paclitaxel albumin-stabilized } \\
\text { nanoparticle formulation in } \\
\text { treating older patients with } \\
\text { locally advanced or metastatic } \\
\text { breast cancer }\end{array}$ & $\begin{array}{l}\text { Active, not } \\
\text { recruiting }\end{array}$ & $\begin{array}{l}\text { Drug: paclitaxel albumin- } \\
\text { stabilized nanoparticle } \\
\text { formulation } \\
\text { Other: questionnaire } \\
\text { administration }\end{array}$ & $\begin{array}{l}\text { November I, } \\
2011\end{array}$ & $\begin{array}{l}\text { National Cancer } \\
\text { Institute } \\
\text { City of Hope } \\
\text { Medical Center }\end{array}$ & Arti Hurria \\
\hline $\begin{array}{l}\text { Veliparib in treating patients with } \\
\text { malignant solid tumors that do } \\
\text { not respond to previous therapy }\end{array}$ & $\begin{array}{l}\text { Active, not } \\
\text { recruiting }\end{array}$ & $\begin{array}{l}\text { Other: laboratory } \\
\text { biomarker analysis } \\
\text { Other: pharmacologic study } \\
\text { Drug: veliparib }\end{array}$ & May 4, 2009 & $\begin{array}{l}\text { National Cancer } \\
\text { Institute }\end{array}$ & $\begin{array}{l}\text { Shannon } \\
\text { Puhalla }\end{array}$ \\
\hline $\begin{array}{l}\text { Neoadjuvant } \\
\text { pembrolizumab(Pbr)/Nab- } \\
\text { paclitaxel followed by pbr/ } \\
\text { epirubicin/cyclophosphamide } \\
\text { in TNBC }\end{array}$ & $\begin{array}{l}\text { Not yet } \\
\text { recruiting }\end{array}$ & $\begin{array}{l}\text { Drug: pembrolizumab } \\
\text { Drug: nab-paclitaxel } \\
\text { Drug: epirubicin } \\
\text { Drug: cyclophosphamide }\end{array}$ & $\begin{array}{l}\text { September 21, } \\
2017\end{array}$ & $\begin{array}{l}\text { Merck Sharp \& } \\
\text { Dohme Corp. } \\
\text { Celgene } \\
\text { Corporation } \\
\text { Institut fuer } \\
\text { Frauengesundheit }\end{array}$ & $\begin{array}{l}\text { Peter A } \\
\text { Fasching }\end{array}$ \\
\hline $\begin{array}{l}\text { Phase II study with abraxane, } \\
\text { bevacizumab and carboplatin in } \\
\text { triple negative metastatic breast } \\
\text { cancer }\end{array}$ & Completed* & $\begin{array}{l}\text { Drug: abraxane } \\
\text { Drug: bevacizumab } \\
\text { Drug: carboplatin }\end{array}$ & May 28, 2007 & $\begin{array}{l}\text { Duke University } \\
\text { Genentech, Inc. } \\
\text { Celgene } \\
\text { Corporation }\end{array}$ & $\begin{array}{l}\text { Kimberly } \\
\text { Blackwell }\end{array}$ \\
\hline $\begin{array}{l}\text { AZD228I plus carboplatin to } \\
\text { treat breast and ovarian cancer }\end{array}$ & Completed & Drug: AZ228I+carboplatin & $\begin{array}{l}\text { October 3, } \\
2011\end{array}$ & $\begin{array}{l}\text { National Cancer } \\
\text { Institute }\end{array}$ & Jung-Min Lee \\
\hline $\begin{array}{l}\text { An efficacy study of trabectedin } \\
\text { in the treatment of participants } \\
\text { with specific subtypes of } \\
\text { metastatic breast cancer }\end{array}$ & Completed & $\begin{array}{l}\text { Drug: dexamethasone } \\
\text { Drug: trabectedin }\end{array}$ & $\begin{array}{l}\text { December 24, } \\
2007\end{array}$ & $\begin{array}{l}\text { Johnson \& Johnson } \\
\text { Pharmaceutical } \\
\text { Research and } \\
\text { Development, LLC } \\
\text { PharmaMar }\end{array}$ & $\begin{array}{l}\text { Not } \\
\text { mentioned }\end{array}$ \\
\hline $\begin{array}{l}\text { Study of abraxane and } \\
\text { carboplatin as first-line treatment } \\
\text { for triple negative metastatic } \\
\text { breast cancer }\end{array}$ & Terminated* & $\begin{array}{l}\text { Drug: abraxane } \\
\text { Drug: carboplatin }\end{array}$ & $\begin{array}{l}\text { September 22, } \\
2010\end{array}$ & $\begin{array}{l}\text { Duke University } \\
\text { Celgene } \\
\text { Corporation }\end{array}$ & $\begin{array}{l}\text { Kimberly L } \\
\text { Blackwell }\end{array}$ \\
\hline
\end{tabular}

Note: *Studies that have results. 
Table 7 Top 10 cited papers in the area of nanotechnology and triple negative breast cancer

\begin{tabular}{|c|c|c|c|c|c|}
\hline Authors and journal & Article & Main results & $\begin{array}{l}\text { Total } \\
\text { citations }\end{array}$ & $\begin{array}{l}\text { Average } \\
\text { citations } \\
\text { per year }\end{array}$ & References \\
\hline $\begin{array}{l}\text { Hrkach J, et al. Science } \\
\text { Translational Medicine. } \\
\text { 20I2;4(I28):I28ra39 }\end{array}$ & $\begin{array}{l}\text { Preclinical development and clinical } \\
\text { translation of a PSMA-targeted } \\
\text { docetaxel nanoparticle with a } \\
\text { differentiated pharmacological } \\
\text { profile }\end{array}$ & $\begin{array}{l}\text { Docetaxel encapsulated in polymeric } \\
\text { nanoparticle exhibited enhanced tumor } \\
\text { accumulation and prolonged tumor growth } \\
\text { suppression in low doses also, compared to } \\
\text { that typically used in the clinic }\end{array}$ & 445 & 88.2 & 37 \\
\hline $\begin{array}{l}\text { Ohno S-I, et al. Molecular } \\
\text { Therapy.20|3;2I (I):|85-19| }\end{array}$ & $\begin{array}{l}\text { Systemically injected exosomes } \\
\text { targeted to EGFR deliver antitumor } \\
\text { microRNA to breast cancer cells }\end{array}$ & $\begin{array}{l}\text { Exosomes can efficiently deliver miRNA to } \\
\text { EGFR-expressing breast cancer cells, also } \\
\text { can be used therapeutically to target EGFR- } \\
\text { expressing cancerous tissues with acid drugs }\end{array}$ & 291 & 70.5 & 38 \\
\hline $\begin{array}{l}\text { Danhier F, Breton AL, Préat V. } \\
\text { Molecular Pharmaceutics. } \\
\text { 20I2;9(I I):296I-2973 }\end{array}$ & $\begin{array}{l}\text { RGD-based strategies to target } \\
\text { alpha(v) beta ( } 3 \text { ) integrin in cancer } \\
\text { therapy and diagnosis }\end{array}$ & $\begin{array}{l}\text { This review aims to highlight the position of } \\
\text { RGD-based nanoparticles in cancer therapy } \\
\text { and imaging }\end{array}$ & 283 & 55.4 & 39 \\
\hline $\begin{array}{l}\text { Ge J, et al. Nature } \\
\text { Communications. } \\
\text { 2014;5:4596 }\end{array}$ & $\begin{array}{l}\text { A graphene quantum dot } \\
\text { photodynamic therapy agent with } \\
\text { high singlet oxygen generation }\end{array}$ & $\begin{array}{l}\text { Graphene quantum dots can be used as } \\
\text { photodynamic agents allowing imaging and } \\
\text { providing a highly efficient cancer therapy }\end{array}$ & 219 & 71.7 & 40 \\
\hline $\begin{array}{l}\text { Yuan H, Fales AM, Vo- } \\
\text { Dinh T. Journal of the } \\
\text { American Chemical Society. } \\
2012 ; \mid \text { 34(28): I |358-I |36| }\end{array}$ & $\begin{array}{l}\text { TAT peptide-functionalized gild } \\
\text { nanostars: enhanced intracellular } \\
\text { delivery and efficient NIR photo- } \\
\text { thermal therapy using ultralow } \\
\text { irradiance }\end{array}$ & $\begin{array}{l}\text { The entrance of TAT-peptide-functionalized } \\
\text { gold nanostars in the cells is increased after } \\
\text { photothermolysis, enhancing its intracellular } \\
\text { delivery and action }\end{array}$ & 212 & 41.4 & 41 \\
\hline $\begin{array}{l}\text { Cheng L, et al. Biomaterials. } \\
\text { 2012;33(7):2215-2222 }\end{array}$ & $\begin{array}{l}\text { Multifunctional nanoparticles for } \\
\text { upconversion luminescence/MR } \\
\text { multimodal imaging and magnetically } \\
\text { targeted photothermal therapy }\end{array}$ & $\begin{array}{l}\text { Multifunctional nanoparticles under application } \\
\text { of near-infrared laser irradiation promotes } \\
\text { photothermal therapeutic efficacy with } 100 \% \\
\text { tumor elimination in in vivo model }\end{array}$ & 208 & $4 I .4$ & 42 \\
\hline $\begin{array}{l}\text { King HW, Michael MZ, } \\
\text { Gleadle JM. BMC Cancer. } \\
\text { 20I2;12:42I }\end{array}$ & $\begin{array}{l}\text { Hypoxic enhancement of exosome } \\
\text { release by breast cancer cells }\end{array}$ & $\begin{array}{l}\text { Hypoxia promotes the release of exosomes } \\
\text { by breast cancer cells mediated by HIF-I } \alpha\end{array}$ & 166 & 32.4 & 43 \\
\hline $\begin{array}{l}\text { Amoozgar Z, Yeo T. } \\
\text { Wiley Interdisciplinary } \\
\text { Reviews: Nanomedicine } \\
\text { and Nanobiotechnology. } \\
2012 ; 4(2): 219-233\end{array}$ & $\begin{array}{l}\text { Recent advances in stealth coating } \\
\text { of nanoparticle drug delivery } \\
\text { systems }\end{array}$ & $\begin{array}{l}\text { This review aims to disseminate strategies } \\
\text { to improve the action of nanoparticles using } \\
\text { different synthesis methods and to present } \\
\text { general characteristics about it }\end{array}$ & 156 & 31.0 & 44 \\
\hline $\begin{array}{l}\text { Pecot CV, et al. Nature } \\
\text { Communications. } \\
\text { 20I3;4:2427 }\end{array}$ & $\begin{array}{l}\text { Tumour angiogenesis regulation by } \\
\text { the miR-200 family }\end{array}$ & $\begin{array}{l}\text { miR-200 inhibits angiogenesis in several cancer } \\
\text { types through direct and indirect mechanisms } \\
\text { by targeting interleukin- } 8 \text { and } \mathrm{CXClI} \text { secreted } \\
\text { by tumor endothelial and cancer cells }\end{array}$ & 126 & 31.2 & 45 \\
\hline $\begin{array}{l}\text { She W, et al. Biomaterials. } \\
2013 ; 34(9): 2252-2264\end{array}$ & $\begin{array}{l}\text { Dendronized heparin-doxorubicin } \\
\text { conjugate-based nanoparticle as } \\
\mathrm{pH} \text {-responsive drug delivery system } \\
\text { for cancer therapy }\end{array}$ & $\begin{array}{l}\text { The nanoparticles were shown to effectively kill } \\
\text { cancer cells in vitro, showed strong antitumor } \\
\text { activity, showed high antiangiogenesis effects, } \\
\text { and induced apoptosis in vivo }\end{array}$ & 118 & 29.0 & 46 \\
\hline
\end{tabular}

Abbreviation: HIF, hypoxia-inducible factor.

(193 times cited, 2015) as the more recently used keywords (Figure 6). The density map shows the citation concentration areas for keywords (Figure 7).

\section{Conclusion}

Nanotechnology cancer field has the potential for improving therapeutic efficacy, creating methods for detection, and targeting different cancer stages. Development of various nanomaterials and nanotechnology had allowed the improvement of cancer biomarkers area with high precision and sensibility that was not the case some years ago. In this study, the global scientific production from the period ranging from 2012 to 2017 related to the nanotechnology applied to TNBC research was analyzed quantitatively and qualitatively. Results showed an increase in the cumulative volume of papers worldwide and a tendency to continue growing in terms of publication numbers. Research has focused on the search for drug carrier systems for the treatment of breast cancer in in vitro studies using the MCF-7 cell line and animal models, specifically Bagg albino mouse. Thus, through the study of the quantitative aspects of the production and dissemination of the 


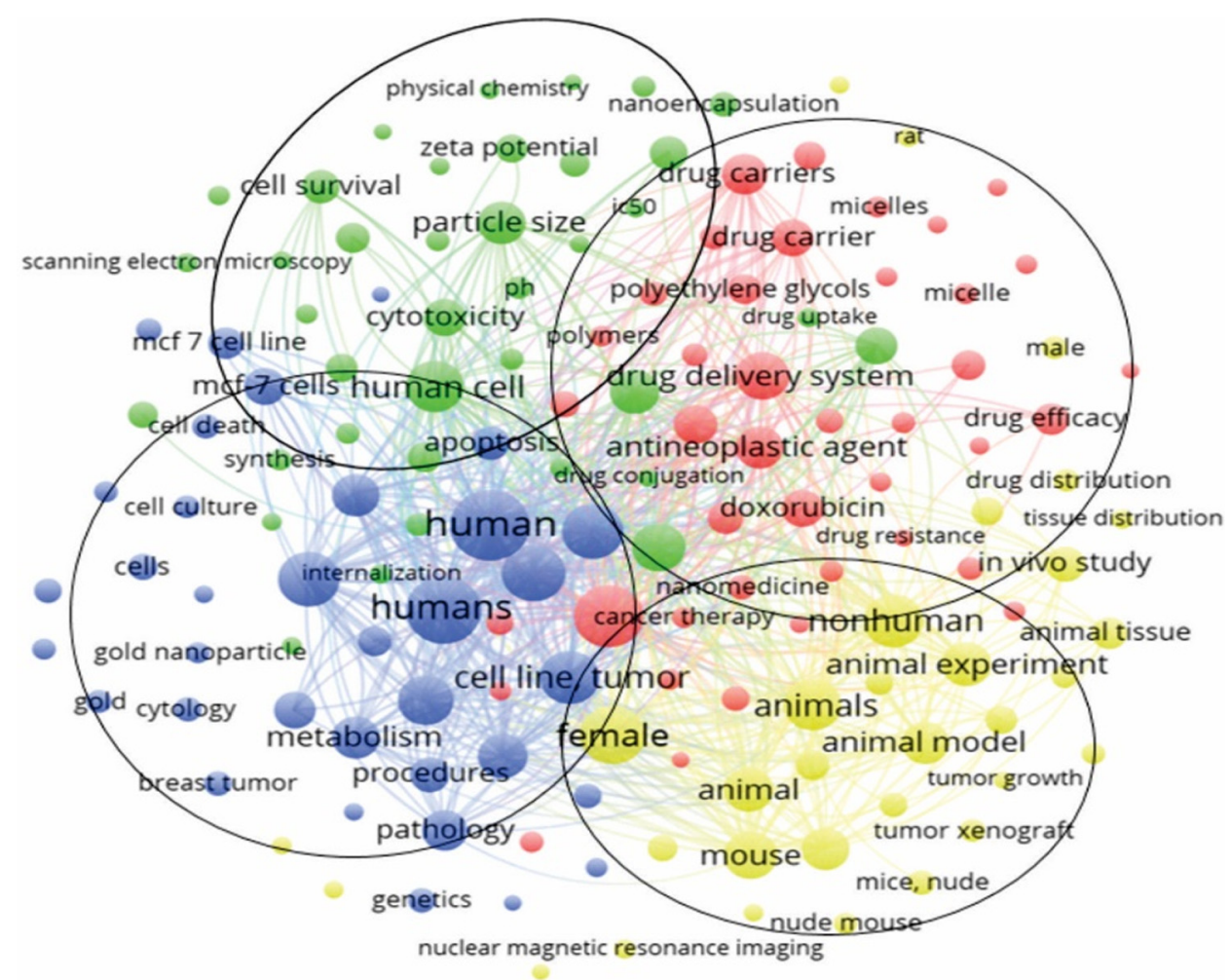

Figure 5 Association line of keywords from papers in the area of nanotechnology and triple negative breast cancer.

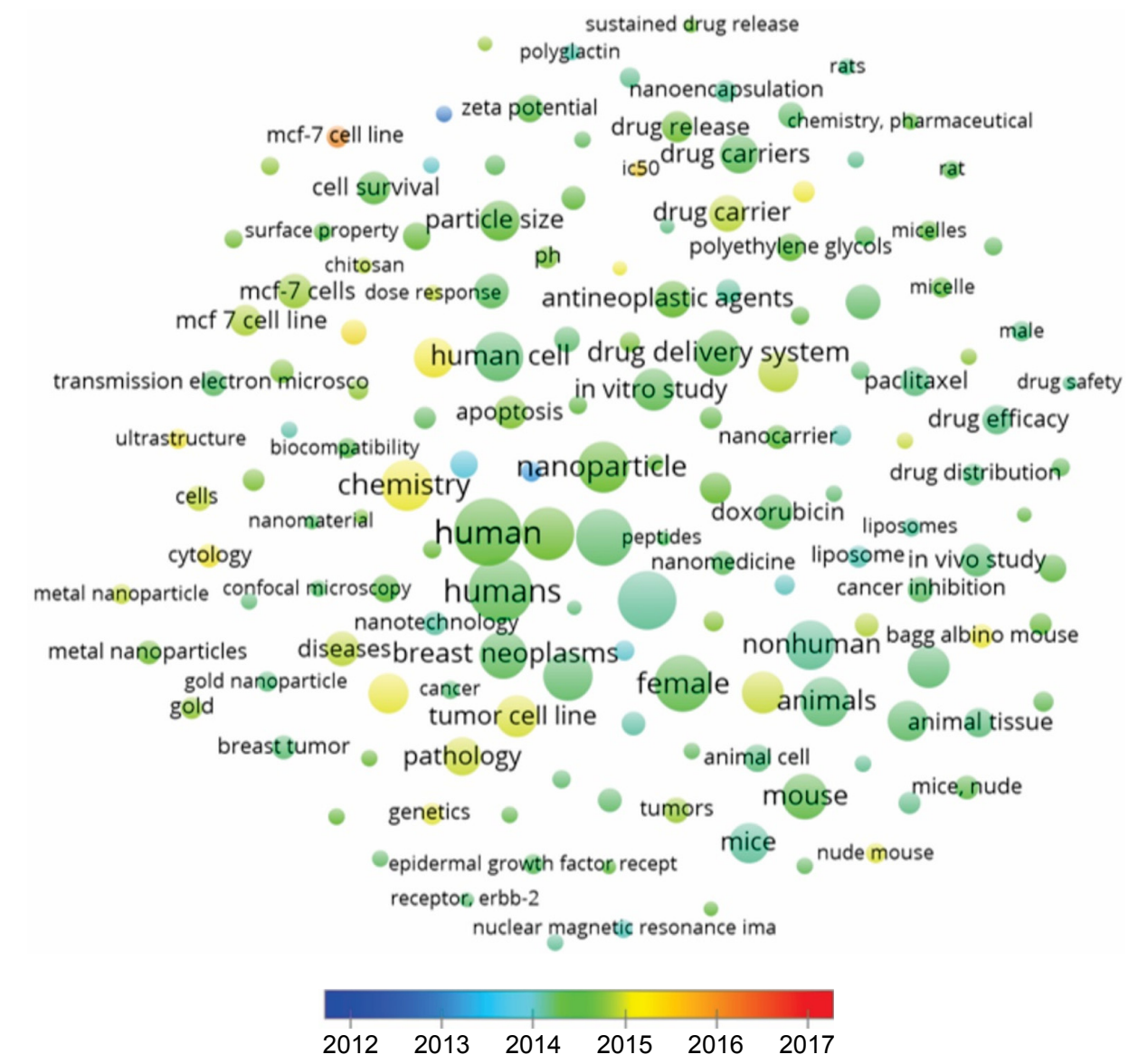

Figure 6 Average year map of keywords. 


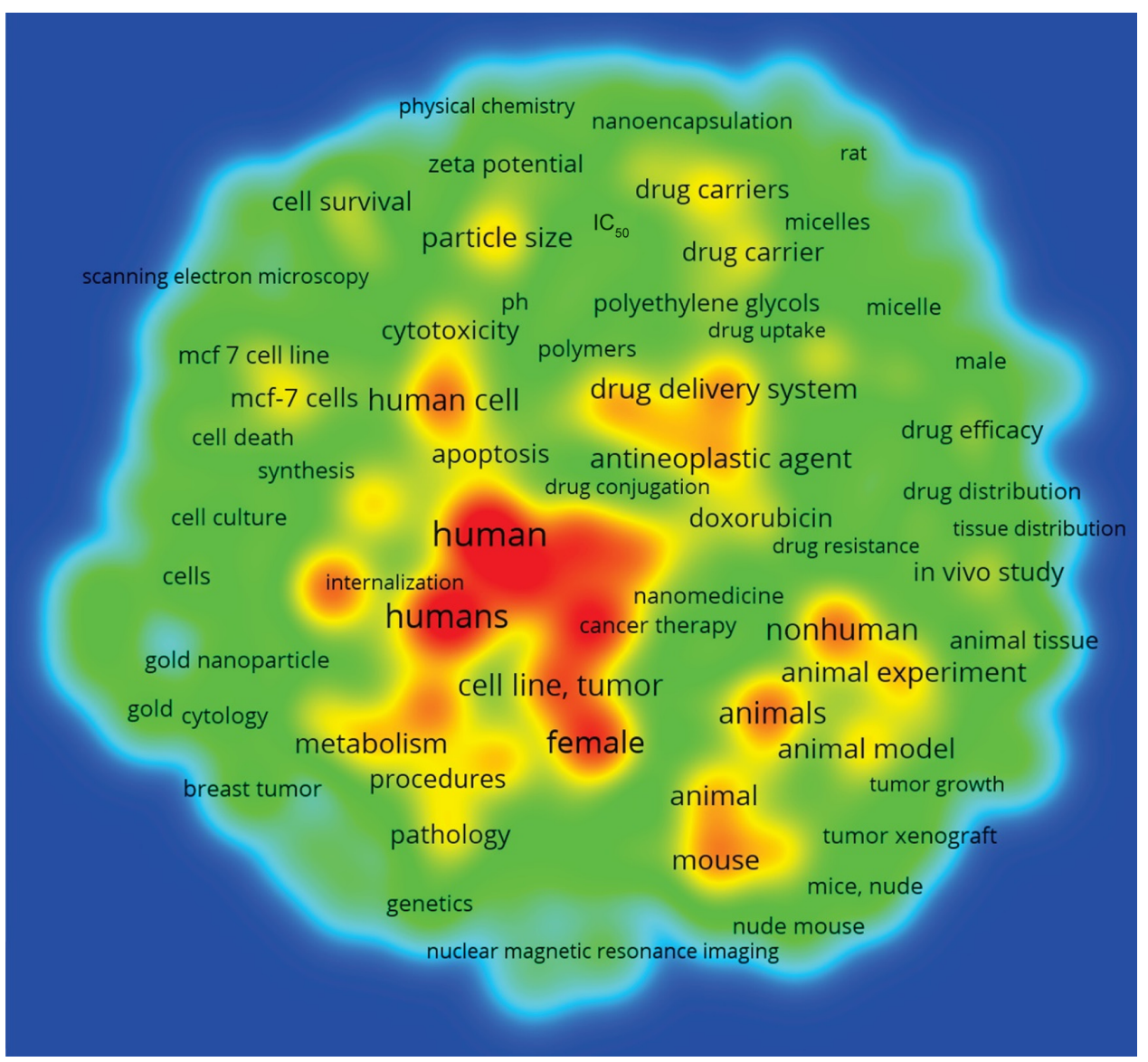

Figure 7 Density map of keywords.

knowledge generated in the time interval observed through bibliometric analysis, it was possible to trace the research profiles of different countries, centers, and researchers, offering an important analysis of the scientific production, behavior, and development in this field of research.

\section{Acknowledgments}

We acknowledge Camila Umbelino Carvalho e Fernando Vieira da Silva for helping us in programming language and performing graphs in software RSudio 1.1.383. This work was supported by São Paulo Research Foundation (FAPESP grants \#2017/19504-0 and 2018/06003-5).

\section{Author contributions}

All three authors have made substantial contributions to the acquisition, analysis and interpretation of the data in this study. All authors also critically revised the manuscript. The authors agree to be accountable for all aspects of the work.

\section{Disclosure}

The authors report no conflicts of interest in this work.

\section{References}

1. Bloom DE, Cafiero E, Jané-Llopis E, et al. The global economic burden of noncommunicable diseases. World Econ Forum. 2011:1-46.

2. Pavlova NN, Thompson CB: The Emerging Hallmarks of Cancer Metabolism. Cell Metab. 2016;23:27-47.

3. Weber CE, Kuo PC. The tumor microenvironment. Surg Oncol. 2012; 21:172-177.

4. Stratton MR, Campbell PJ, Futreal PA. The cancer genome. Nature. 2009;458:719-724.

5. Davidson NE, Armstrong SA, Coussens LM, et al. AACR Cancer Progress Report 2016. Clin Cancer Res. 2016;22(19 suppl):S1-S137.

6. Engebraaten O, Vollan HKM, Børresen-Dale A-L. Triple-negative breast cancer and the need for new therapeutic targets. Am J Pathol. 2013; 183:1064-1074.

7. Banerji S, Cibulskis K, Rangel-Escareno C, et al. Sequence analysis of mutations and translocations across breast cancer subtypes. Nature. 2012;486:405-409.

8. Abramson VG, Lehmann BD, Ballinger TJ, Pietenpol JA. Subtyping of triple-negative breast cancer: implications for therapy. Cancer. 2015;121:8-16.

9. Plasilova ML, Hayse B, Killelea BK, Horowitz NR, Chagpar AB, Lannin DR. Features of triple-negative breast cancer. Medicine (Baltimore). 2016;95:e4614.

10. Lu J, Liong M, Li Z, Zink JI, Tamanoi F. Biocompatibility, biodistribution, and drug-delivery efficiency of mesoporous silica nanoparticles for cancer therapy in animals. Small. 2010;6:1794-1805.

11. Filgueiras MDC, Morrot A, Soares PMG, Costa ML, Mermelstein C. Effects of 5-fluorouracil in nuclear and cellular morphology, proliferation, cell cycle, apoptosis, cytoskeletal and caveolar distribution in primary cultures of smooth muscle cells. PLoS One. 2013;8(4):e63177. 
12. Fallis A. Cancer nanotechnology plan 2015. J Chem Inf Model. 2013; 53:1689-1699.

13. Wang M, Thanou M. Targeting nanoparticles to cancer. Pharmacol Res. 2010;62:90-99.

14. Park K, Lee S, Kang E, Kim K, Choi K, Kwon IC. New generation of multifunctional nanoparticles for cancer imaging and therapy. Adv Funct Mater. 2009;19:1553-1566.

15. Mu Q, Wang H, Zhang M. Nanoparticles for imaging and treatment of metastatic breast cancer. Expert Opin Drug Deliv. 2017;14(1):123-136.

16. Huang Y, Fan C-Q, Dong H, Wang S-M, Yang X-C, Yang S-M. Current applications and future prospects of nanomaterials in tumor therapy. Int J Nanomed. 2017;12:1815-1825.

17. Feng B, Xu Z, Zhou F, et al. Near infrared light-actuated gold nanorods with cisplatin-polypeptide wrapping for targeted therapy of triple negative breast cancer. Nanoscale. 2015;7:14854-14864.

18. Zhao J, Babiuch K, Lu H, Dag A, Gottschaldt M, Stenzel MH. Fructosecoated nanoparticles: a promising drug nanocarrier for triple-negative breast cancer therapy. Chem Commun. 2014;50:15928-15931.

19. Englert C, Pröhl M, Czaplewska JA, et al. d-Fructose-decorated poly(ethylene imine) for human breast cancer cell targeting. Macromol Biosci. 2017;17(8).

20. Zhou X, Qin X, Gong T, Zhang Z-R, Fu Y. d-Fructose modification enhanced internalization of mixed micelles in breast cancer cells via GLUT5 transporters. Macromol Biosci. 2017;17(7).

21. Li Y, Pei Y, Zhang X, et al. PEGylated PLGA nanoparticles as protein carriers: synthesis, preparation and biodistribution in rats. $J$ Control Release. 2001;71:203-211.

22. Tang S, Yin Q, Zhang Z, et al. Co-delivery of doxorubicin and RNA using $\mathrm{pH}$-sensitive poly ( $\beta$-amino ester) nanoparticles for reversal of multidrug resistance of breast cancer. Biomaterials. 2014;35:6047-6059.

23. Dinarvand R, Sepehri N, Manoochehri S, Rouhani H, Atyabi F. Polylactide-co-glycolide nanoparticles for controlled delivery of anticancer agents. Int J Nanomedicine. 2011;6:877-895.

24. Taheri A, Dinarvand R, Ahadi F, Khorramizadeh MR, Atyabi F. The in vivo antitumor activity of LHRH targeted methotrexate -human serum albumin nanoparticles in 4T1 tumor-bearing Balb/c mice. Int J Pharm. 2012;431:183-189.

25. Duan X, Xiao J, Yin Q, Zhang Z, Yu H, Mao S, Li Y: Smart pHSensitive and Temporal-Controlled Polymeric Micelles for Effective Combination Therapy of Doxorubicin and Disulfiram. ACS Nano. 2013; 7:5858-5869.

26. He Q, Zhang Z, Gao F, Li Y, Shi J: In vivo Biodistribution and Urinary Excretion of Mesoporous Silica Nanoparticles: Effects of Particle Size and PEGylation. Small. 2011;7:271-280.

27. Gao Y, Chen Y, Ji X, et al. Controlled Intracellular Release of Doxorubicin in Multidrug-Resistant Cancer Cells by Tuning the Shell-Pore Sizes of Mesoporous Silica Nanoparticles. ACS Nano. 2011;5:9788-9798.

28. Akbarzadeh A, Rezaei-Sadabady R, Davaran S, et al. Liposome: classification, preparation, and applications. Nanoscale Res Lett. 2013;8:102.

29. Ghasemali S, Nejati-Koshki K, Tafsiri E, et al. Inhibitory effects of $\beta$-cyclodextrin-helenalin complexes on H-TERT gene expression in the T47D breast cancer cell line - results of real time quantitative PCR. Asian Pac J Cancer Prev. 2013;14(11):6949-6953.

30. Dai J, Nagai T, Wang X, Zhang T, Meng M, Zhang Q. pH-sensitive nanoparticles for improving the oral bioavailability of cyclosporine A. Int J Pharm. 2004;280(1-2):229-240.

31. Wang Z, Yu Y, Dai W, et al. The use of a tumor metastasis targeting peptide to deliver doxorubicin-containing liposomes to highly metastatic cancer. Biomaterials. 2012;33(33):8451-8460.
32. Zhang Y, Zhang H, Wang X, Wang J, Zhang X, Zhang Q. The eradication of breast cancer and cancer stem cells using octreotide modified paclitaxel active targeting micelles and salinomycin passive targeting micelles. Biomaterials. 2012;33(2):679-691.

33. Feng Q, Yu M-Z, Wang J-C, et al. Synergistic inhibition of breast cancer by co-delivery of VEGF siRNA and paclitaxel via vapreotide-modified core-shell nanoparticles. Biomaterials. 2014;35(18):5028-5038.

34. Faridbod F, Ganjali MR, Dinarvand R, Norouzi P, Riahi S. Schiff's Bases and Crown Ethers as Supramolecular Sensing Materials in the Construction of Potentiometric Membrane Sensors. Sensors (Basel). 2008; 8(3):1645-1703.

35. Ferrari M. Cancer nanotechnology: opportunities and challenges. Nat Rev Cancer. 2005;5(3):161-171.

36. Xu R, Zhang G, Mai J, et al. An injectable nanoparticle generator enhances delivery of cancer therapeutics. Nat Biotechnol. 2016;34: 414-418.

37. Hrkach J, Von Hoff D, Ali MM, et al. Preclinical Development and Clinical Translation of a PSMA-Targeted Docetaxel Nanoparticle with a Differentiated Pharmacological Profile. Sci Transl Med. 2012; 4(128):128ra39.

38. Ohno S, Takanashi M, Sudo K, et al. Systemically injected exosomes targeted to EGFR deliver antitumor microRNA to breast cancer cells. Mol Ther. 2013;21(1):185-191.

39. Danhier F, Le Breton A, Préat V. RGD-Based Strategies To Target Alpha(v) Beta(3) Integrin in Cancer Therapy and Diagnosis. Mol Pharm. 2012;9(11):2961-2973.

40. Ge J, Lan M, Zhou B, et al. A graphene quantum dot photodynamic therapy agent with high singlet oxygen generation. Nat Commun. 2014;5.

41. Yuan H, Fales AM, Vo-Dinh T. TAT Peptide-Functionalized Gold Nanostars: Enhanced Intracellular Delivery and Efficient NIR Photothermal Therapy Using Ultralow Irradiance. J Am Chem Soc. 2012; 134(28):1358-11361.

42. Cheng L, Yang K, Li Y, Zeng X, Shao M, Lee S-T, Liu Z. Multifunctional nanoparticles for upconversion luminescence/MR multimodal imaging and magnetically targeted photothermal therapy. Biomaterials. 2012;33(7):2215-2222.

43. King HW, Michael MZ, Gleadle JM. Hypoxic enhancement of exosome release by breast cancer cells. BMC Cancer. 2012;12:421.

44. Amoozgar Z, Yeo Y. Recent advances in stealth coating of nanoparticle drug delivery systems. Wiley Interdiscip Rev Nanomedicine Nanobiotechnology. 2012;4(2):219-233.

45. Pecot C V., Rupaimoole R, Yang D, et al. Tumour angiogenesis regulation by the miR-200 family. Nat Commun. 2013;4:2427.

46. She W, Li N, Luo K, Guo C, Wang G, Geng Y, Gu Z. Dendronized heparin-doxorubicin conjugate based nanoparticle as $\mathrm{pH}$-responsive drug delivery system for cancer therapy. Biomaterials. 2013;34(9): 2252-2264.

47. Miller-Kleinhenz JM, Bozeman EN, Yang L. Targeted nanoparticles for image-guided treatment of triple-negative breast cancer: Clinical significance and technological advances. Wiley Interdiscip Rev Nanomedicine Nanobiotechnology. 2015;7(6):797-816.

48. Núñez C, Capelo JL, Igrejas G, Alfonso A, Botana LM, Lodeiro C. An overview of the effective combination therapies for the treatment of breast cancer. Biomaterials. 2016;97:34-50. 


\section{Supplementary material}

Table SI List of keywords generated by VOSviewer

\begin{tabular}{|c|c|c|c|c|c|}
\hline Id & Cluster & Links & $\begin{array}{l}\text { Total link } \\
\text { strength }\end{array}$ & Ocurrences & $\begin{array}{l}\text { Avg. pub. } \\
\text { year }\end{array}$ \\
\hline Antibiotics, antineoplasic & I & 142 & 2,748 & 91 & 2014.32 \\
\hline Antineoplasic agent & I & 145 & 15,216 & 544 & 2014.86 \\
\hline Antineoplastic agents & I & 145 & 12,789 & 466 & 2014.52 \\
\hline Antineoplastic agents, phytogenic & I & 144 & 3,049 & 110 & 2014.37 \\
\hline Breast cancer & I & 145 & 25,473 & 1,133 & 2014.20 \\
\hline Cancer & I & 145 & 2,299 & 111 & 2014.31 \\
\hline Cancer chemotherapy & I & 145 & 3,622 & 135 & 2014.11 \\
\hline Cancer therapy & I & 145 & 3,606 & 150 & 2014.02 \\
\hline Chemistry, pharmaceutical & I & 140 & 2,597 & 89 & 2014.53 \\
\hline Chemotherapy & I & 145 & 3,395 & 132 & 2014.67 \\
\hline Docetaxel & 1 & 142 & 3,174 & 128 & 2014.39 \\
\hline Doxorubicin & I & 145 & 10,337 & 395 & 2014.38 \\
\hline Drug carrier & I & 145 & 12,086 & 427 & 2014.87 \\
\hline Drug carriers & I & 145 & 13,199 & 478 & 2014.49 \\
\hline Drug delivery & I & 145 & 5,533 & 226 & 2014.32 \\
\hline Drug delivery system & I & 145 & 17,825 & 666 & 2014.43 \\
\hline Drug delivery systems & I & 145 & 8,691 & 318 & $2014.5 \mid$ \\
\hline Drug efficacy & I & 145 & 8,873 & 299 & $20 \mid 4.26$ \\
\hline Drug formulation & I & 145 & 6,652 & 237 & 2014.35 \\
\hline Drug resistance & I & 145 & 2,946 & 93 & 2014.90 \\
\hline Drug resistance, neoplasm & I & 145 & 3,199 & 110 & 2014.90 \\
\hline Drug safety & I & 137 & 2,056 & 85 & 2014.24 \\
\hline Drug targeting & I & 145 & 3,707 & 137 & 2014.07 \\
\hline Encapsulation & I & 142 & 2,966 & 104 & 2014.22 \\
\hline Epidermal growth receptor 2 & I & 145 & 2,759 & 129 & 2014.37 \\
\hline Liposome & I & 145 & 3,933 & 165 & 2014.10 \\
\hline Liposomes & $\mathrm{I}$ & 144 & 2,916 & 114 & 2014.18 \\
\hline Macrogol & I & 145 & 5,495 & 191 & 2014.18 \\
\hline Macrogol derivate & I & 144 & 5,737 & 177 & 2015.06 \\
\hline Micelle & I & 145 & 4,475 & 149 & 2014.53 \\
\hline Micelles & I & 144 & 4,104 & 137 & 2014.53 \\
\hline Molecularly targeted therapy & I & 145 & 2,453 & 86 & 2014.37 \\
\hline Multigrud resistance & I & 144 & 2,708 & 93 & 2014.69 \\
\hline Nanocarrier & I & 145 & 5,136 & 179 & 2014.50 \\
\hline Nanomedicine & 1 & 145 & 4,366 & 179 & 2014.36 \\
\hline Nanotechnology & 1 & 145 & 3,660 & 200 & 2014.15 \\
\hline Neoplasms & I & 145 & 4,503 & 198 & 2014.15 \\
\hline Paclitaxel & I & 145 & 6,411 & 277 & 2014.26 \\
\hline Polyethylene glycols & I & 145 & 7,772 & 265 & 2014.51 \\
\hline Polymer & I & 145 & 4,412 & 163 & 2014.44 \\
\hline Polymers & I & 145 & 4,078 & 149 & 2014.62 \\
\hline Antineoplastic activity & 2 & 145 & 12,103 & $4 I I$ & 2014.35 \\
\hline Biocompatibility & 2 & 145 & 3,250 & 129 & 2014.44 \\
\hline Breast cancer cell line & 2 & 144 & 6,465 & 231 & 2015.23 \\
\hline Cancer cell & 2 & 145 & 6,297 & 267 & 2013.88 \\
\hline Cancer cell culture & 2 & 143 & 3,361 & 150 & 2013.12 \\
\hline Cell strain MCF-7 & 2 & $14 \mid$ & I,972 & 90 & 2012.83 \\
\hline Cell survival & 2 & 145 & 9,525 & 352 & 2014.43 \\
\hline Cell viability & 2 & 145 & 7,251 & 267 & 2014.50 \\
\hline Chitosan & 2 & 144 & 2,019 & 91 & 2014.87 \\
\hline Concentration response & 2 & 145 & 2,310 & 86 & 2014.05 \\
\hline Confocal microscopy & 2 & 144 & 2,658 & 99 & 2014.35 \\
\hline
\end{tabular}


Table SI (Continued)

\begin{tabular}{|c|c|c|c|c|c|}
\hline Id & Cluster & Links & $\begin{array}{l}\text { Total link } \\
\text { strength }\end{array}$ & Ocurrences & $\begin{array}{l}\text { Avg. pub. } \\
\text { year }\end{array}$ \\
\hline Cytotoxicity & 2 & 145 & 10,253 & 406 & 2014.37 \\
\hline Drug conjugation & 2 & 145 & 3,059 & 103 & 2014.53 \\
\hline Drug cytotoxicity & 2 & 145 & 5,914 & 204 & 2014.47 \\
\hline Drug release & 2 & 145 & 9,809 & 338 & 2014.57 \\
\hline Drug stability & 2 & 145 & 3,688 & 135 & 2014.22 \\
\hline Drug synthesis & 2 & 145 & 3,459 & 132 & 2014.37 \\
\hline Drug uptake & 2 & 145 & 3,290 & 109 & 2014.45 \\
\hline Endocytosis & 2 & 145 & 3,664 & 125 & 2014.46 \\
\hline Flow cytometry & 2 & 145 & 4,128 & 158 & 2914.37 \\
\hline Fluorescence microscopy & 2 & 145 & 2,217 & 89 & 2014.13 \\
\hline Human cell & 2 & 145 & 20,170 & 787 & 2014.32 \\
\hline Hydrogen ion concentration & 2 & 145 & 2,670 & 89 & 2014.37 \\
\hline $\mathrm{IC}_{50}$ & 2 & 143 & 3,263 & 103 & $2015.4 \mid$ \\
\hline In vitro study & 2 & 145 & 16,554 & 584 & 2014.39 \\
\hline Infrared spectroscopy & 2 & 143 & 2,917 & 122 & 2014.70 \\
\hline Internalization & 2 & 145 & 3,244 & 112 & 2014.53 \\
\hline Nanoencapsulation & 2 & 145 & 5,072 & 175 & 2014.21 \\
\hline Particle size & 2 & 145 & 14,569 & 551 & 2014.48 \\
\hline $\mathrm{pH}$ & 2 & 145 & 4,373 & 154 & 2014.63 \\
\hline Physical chemistry & 2 & 145 & 2,814 & 103 & 2014.48 \\
\hline Polyglactin & 2 & 145 & 2,349 & 87 & 2014.11 \\
\hline Scanning electron microscopy & 2 & 144 & 2,429 & 111 & 2014.59 \\
\hline Surface property & 2 & 145 & 2,998 & 113 & 2014.47 \\
\hline Synthesis & 2 & 145 & 3,766 & 138 & 2014.72 \\
\hline Transmission electron microscopy & 2 & 145 & 5,382 & 227 & 2014.34 \\
\hline Unclassified drug & 2 & 145 & 16,929 & 685 & 2014.13 \\
\hline Zeta potential & 2 & 145 & 6,990 & 253 & 2014.44 \\
\hline Apoptosis & 3 & 145 & 9,513 & 354 & 2014.65 \\
\hline Breast cancer cells & 3 & 145 & 2,200 & 105 & 2014.30 \\
\hline Breast neoplasms & 3 & 145 & $|8,16|$ & 729 & 2014.37 \\
\hline Breast tumor & 3 & 145 & 4,316 & 182 & $20 \mid 4.31$ \\
\hline Cell culture & 3 & 145 & 3,973 & 169 & 2014.63 \\
\hline Cell death & 3 & 145 & 5,057 & 193 & 2014.63 \\
\hline Cell line, tumor & 3 & 145 & 21,152 & 814 & 2014.33 \\
\hline Cell proliferation & 3 & 145 & 6,910 & 263 & 2014.48 \\
\hline Cells & 3 & 145 & 5,212 & 226 & 2914.90 \\
\hline Chemistry & 3 & 145 & 22,331 & 855 & 2015.02 \\
\hline Cytology & 3 & 145 & 4,356 & 187 & 2015.14 \\
\hline Diseases & 3 & 145 & 9,406 & 400 & 2014.87 \\
\hline Dose response & 3 & 145 & 2,356 & 87 & 2014.91 \\
\hline Drug effects & 3 & 145 & 15,154 & 527 & 2015.11 \\
\hline Gene expression & 3 & 142 & 2,240 & 96 & 2014.54 \\
\hline Genetics & 3 & 145 & 4,557 & 178 & 2014.98 \\
\hline Gold & 3 & 143 & 3,108 & 161 & 2014.73 \\
\hline Gold nanoparticle & 3 & 144 & 2,840 & 148 & 2014.28 \\
\hline Human & 3 & 145 & 33,652 & $|, 48|$ & 2014.47 \\
\hline Humans & 3 & 145 & 31,754 & 1,340 & 2014.39 \\
\hline MCF-7 cell line & 3 & 145 & 8,507 & 308 & 2014.82 \\
\hline MCF-7 cell lines & 3 & 143 & 4,219 & 165 & 2016.04 \\
\hline MCF-7 cells & 3 & 145 & 10,907 & 419 & 2014.75 \\
\hline Metabolism & 3 & 145 & 13,700 & 530 & 2014.99 \\
\hline Metal nanoparticle & 3 & 144 & 2,822 & 146 & 2014.90 \\
\hline Metal nanoparticles & 3 & 143 & 3,623 & 191 & $2014.6 \mathrm{I}$ \\
\hline Nanoparticle & 3 & 145 & 20,739 & 856 & 2014.54 \\
\hline Nanoparticles & 3 & 145 & 21,557 & 918 & 2014.55 \\
\hline Pathology & 3 & 145 & 12,505 & 474 & 2014.92 \\
\hline
\end{tabular}


Table SI (Continued)

\begin{tabular}{|c|c|c|c|c|c|}
\hline Id & Cluster & Links & $\begin{array}{l}\text { Total link } \\
\text { strength }\end{array}$ & Ocurrences & $\begin{array}{l}\text { Avg. pub. } \\
\text { year }\end{array}$ \\
\hline Procedures & 3 & 145 & 9,188 & 368 & 2015.16 \\
\hline Protein expression & 3 & 145 & 5,090 & 200 & 2014.33 \\
\hline RNA, small interfering & 3 & 143 & 2,303 & 86 & 2014.43 \\
\hline Small interfering RNA & 3 & 145 & 2,952 & 120 & 2014.33 \\
\hline Tumor cell line & 3 & 145 & 16,200 & 584 & 2014.95 \\
\hline Ultrastructure & 3 & 144 & 3,356 & 129 & 2015.16 \\
\hline Animal & 4 & 145 & 16,923 & 563 & 2014.90 \\
\hline Animal cell & 4 & 145 & 7,522 & 262 & 2014.27 \\
\hline Animal experimente & 4 & 145 & 17,049 & 571 & 2014.31 \\
\hline Animal model & 4 & 145 & 15,890 & 524 & 2014.33 \\
\hline Animal tissue & 4 & 145 & 8,724 & 293 & 2014.27 \\
\hline Animals & 4 & 145 & 22,161 & 793 & 2014.29 \\
\hline Bagg albino mouse & 4 & 145 & 6,713 & 193 & 2015.00 \\
\hline Cancer inhibition & 4 & 145 & 7,263 & 231 & 2014.35 \\
\hline Drug distribuition & 4 & 145 & 5,077 & 157 & $20 \mid 4.28$ \\
\hline Drug screening & 4 & 145 & 5,716 & 180 & 2014.83 \\
\hline Female & 4 & 145 & 25,711 & 1,023 & 2014.41 \\
\hline In vivo study & 4 & 145 & 11,108 & 360 & 2014.31 \\
\hline Magnetic resonance imaging & 4 & 142 & 2,176 & 87 & \\
\hline Magnetite nanoparticle & 4 & 144 & 2,027 & 90 & 2014.50 \\
\hline Magnetite nanoparticles & 4 & 142 & 2,119 & 95 & 2014.35 \\
\hline Male & 4 & 145 & 4,262 & $|5|$ & 2014.26 \\
\hline Mice & 4 & 145 & 14,860 & 517 & 2014.18 \\
\hline Mice, inbred balb c & 4 & 145 & 8,385 & 256 & 2014.44 \\
\hline Mice, nude & 4 & 145 & 6,470 & 194 & 2014.43 \\
\hline Mouse & 4 & 145 & 19,679 & 679 & 2014.42 \\
\hline Nonhuman & 4 & 145 & 21,738 & 802 & 2014.20 \\
\hline Nuclear magnetic resonance imaging & 4 & 144 & 2,582 & 113 & \\
\hline Nude mouse & 4 & 145 & 5,420 & 149 & 2014.97 \\
\hline Rat & 4 & 145 & 3,456 & 124 & 2014.43 \\
\hline Rats & 4 & 143 & 2,374 & 91 & 2014.24 \\
\hline Tissue distribuition & 4 & 145 & 3,387 & 114 & 2014.39 \\
\hline Treatment outcome & 4 & 144 & 2,351 & 91 & 2014.37 \\
\hline Tumor growth & 4 & 145 & 2,848 & 93 & 2014.22 \\
\hline Tumor volume & 4 & 145 & 4,774 & 153 & 2014.52 \\
\hline Tumor xenograft & 4 & 145 & 4,757 & 154 & 2014.24 \\
\hline Tumors & 4 & 145 & 5,707 & 218 & 2014.76 \\
\hline Xenograft model antitumor assays & 4 & 145 & 4,978 & 150 & $2014.4 I$ \\
\hline
\end{tabular}

International Journal of Nanomedicine

\section{Dovepress}

\section{Publish your work in this journal}

The International Journal of Nanomedicine is an international, peerreviewed journal focusing on the application of nanotechnology in diagnostics, therapeutics, and drug delivery systems throughout the biomedical field. This journal is indexed on PubMed Central, MedLine, CAS, SciSearch $®$, Current Contents ${ }^{\circledR} /$ Clinical Medicine,
Journal Citation Reports/Science Edition, EMBase, Scopus and the Elsevier Bibliographic databases. The manuscript management system is completely online and includes a very quick and fair peer-review system, which is all easy to use. Visit http://www.dovepress.com/ testimonials.php to read real quotes from published authors. 